\title{
FOREWORD TO THE SECOND EDITION
}

The form and content of the study of theology in the present epoch are marked by a vast quantity of the most diverse and, at times, the most divergent points of departure. The classical unity and perspicuity of the world of theological thought, so typical for preceding centuries, has dissolved with the plurality of horizons and problems of modern thinking. The reality of the world, science, and theology no longer appears as a single "orbis," but rather as an open and unbounded space. Indeed, the catchphrase "a new vastness" thus appears to hold as well for the study of theology in modern universities.

This book is intended to provide interested Christians and theologians, especially students of theology, with an access to Karl Rahner; it is also intended to unpack his thinking and to make a theological inspection of his work possible. In this respect it is essential to locate the central point of departure for the theology of Karl Rahner in the concerns and questions of human beings and, taking cues from the key concept of the "anthropological point of departure," to make understandable the underlying tendency of Rahner's work.

Of necessity, mastering scientific inquiries in the everyday praxis of contemporary theological studies often takes the unsatisfactory form of a compilation of various essays, articles, and contributions to handbooks. Precisely for this reason, immersing oneself in the work of an epochally significant author, in the world of his thoughts, and in his theological profile-as here in the case of the theology of 
Karl Rahner-ought to be, not only a dutiful exercise, but a delightful change of pace, perhaps even a passionstudium in the proper sense of the word.

Anton Losinger

Augsburg, April 1992 